\title{
KEEFEKTIFAN PENGAJARAN KOSAKATA BAHASA INGGRIS PADA ANAK SEKOLAH DASAR DENGAN MENGGUNAKAN FLASH CARD
}

\author{
Ni Putu Lindawati \\ niputulindawati@yahoo.com
}

\begin{abstract}
Giving the right stimulus in early stage of age gives a very great impact to the next human development process. There are many methods that we can apply for balancing the right brain and the left brain capability. One of them is using a flash card as a media which uses a card game. Flash card is an effective media to teach children in reading a text and knowing their surrounding in an early age. Trough flash card we can introduce colours,animals, letters, numbers, and other things. In principle, introducing the learning materials trough flash card can be delivered in a simple way and the most important is a pleasure atmosphere both for the children (the learner) and the teacher. Therefore, we can conclude that eventhough the learning process only takes a few minutes but it gives a big benefit for our children.
\end{abstract}

Key words: Effectiveness, Vocabulary, Flash Card

\begin{abstract}
Abstrak
Memberikan stimulus yang tepat dalam tahap awal usia memberikan dampak yang sangat besar untuk proses pembangunan manusia yang berikutnya. Ada banyak metode yang kita dapat terapkan untuk menyeimbangkan kemampuan otak kiri dan otak kanan. Salah satunya adalah menggunakan kartu flash sebagai media yang menggunakan permainan kartu. Kartu flash adalah media yang efektif untuk mengajar anak-anak dalam membaca teks dan mengetahui sekitarnya di usia dini. Palung kartu flash kami dapat memperkenalkan warna, hewan, huruf, angka, dan lain-lain. Pada prinsipnya, memperkenalkan bahan-bahan belajar, palung kartu flash dapat dikirim dalam cara yang sederhana dan yang paling penting adalah suasana kesenangan yang baik untuk anak-anak (pelajar) dan guru. Oleh karena itu, kita dapat menyimpulkan bahwa meskipun proses belajar hanya membutuhkan waktu beberapa menit tapi ini memberikan manfaat besar untuk anak-anak kita.
\end{abstract}

Kata kunci: Efektivitas, Kosa kata, Kartu Flash

\section{A. Pendahuluan}

Pada saat ini, bahasa Inggris menjadi bahasa penting di era globalisasi. Semua orang dituntut untuk mampu berkomunikasi dalam bahasa internasional. Untuk mempersiapkan siswa dalam penguasaan bahasa Inggris sebagai bahasa internasional guru SD memerlukan metode yang tepat untuk mengajarkan siswa. Proporsi bahan mengajar untuk pelajar SD berbeda dari peserta didik dewasa. Bahan ajar kepada siswa menekankan kemampuan untuk memperkaya kosakata untuk pelajar dewasa. Mereka memiliki motivasi dan karakteristik yang berbeda. Ini akan menjadi sulit ketika guru tidak bisa memotivasi pelajar muda. Motivasi dari pelajar muda dalam belajar hanya untuk mendapatkan hal yang baru dalam kehidupan mereka saat bermain. Jadi, itulah sebabnya mereka hanya ingin belajar adalah dengan bermain. Bagi guru, mereka harus menciptakan teknik mengajar yang membuat peserta didik tertarik pada apa yang akan mereka ajarkan kepada siswa, dan menghindari kebosanan. Biasanya siswa di sekolah dasar masih memiliki kosakata yang terbatas, karena mereka mendapatkan kesulitan untuk menghafal makna, dan 
mengucapkan kata dalam bahasa Inggris. Kosakata merupakan hal yang sangat penting dan mendasar dalam pembelajar bahasa. Tanpa kosakata yang memadai, seseorang tidak dapat berkomunikasi dengan efektif atau mengekspresikan ide-idenya baik dalam bentuk lisan maupun tulisan. Selain kosakata, yang perlu diperhatikan juga adalah awalan dan akhiran infleksi dan awalan dan akhiran derivasi (Anggayana, Budasi, \& Suarnajaya 2014). Tak bisa dipungkiri bahwa kosakata tumbuh melalui belajar secara insidental seperti melalui paparan terus-menerus untuk bahasa yang mudah dipahami dalam membaca, mendengarkan, berbicara, dan menulis latihan (Krashen, 1984:74). Dalam belajar bahasa Inggris, kosakata memainkan peran penting dalam empat keterampilan bahasa Inggris, seperti apa yang Schmite dan Carthy (1997:6) mengatakan bahwa kosakata memiliki peran penting dalam kemampuan bahasa.

Berdasarkan fenomena di atas, penulis mencoba untuk menemukan solusi yang efektif untuk meningkatkan kosakata penguasaan dengan menggunakan media flash card. Hal ini karena metode yang biasa digunakan dalam kelas monoton, sehingga siswa merasa bosan. Metode yang monoton membuat siswa malas untuk belajar bahasa Inggris dan tidak tertarik dalam bahasa Inggris. Akhirnya, penguasaan kosakata siswa jadi terbatas. Dengan menggunakan media ajar flash card akan membuat siswa tertarik dalam bahasa Inggris. Ini memberikan cara untuk membuat pengajaran kosakata yang mudah dan efektif.

\section{B. Pembahasan}

\section{Penguasaan Kosakata}

Penguasaan

merupakan salah satu komponen dasar untuk menguasai bahasa Inggris sebagai bahasa asing di tingkat dasar, menengah dan lanjutan. Dalam belajar empat keterampilan berbahasa (mendengarkan, berbicara, membaca, dan menulis), kosakata salah satu komponen dasar yang harus dikuasai. Hal ini wajar, mengingat bahwa empat keterampilan berbahasa membutuhkan pengetahuan tentang kata-kata karena mereka tidak akan mendapatkan apa-apa tanpa kosakata. Semakin banyak siswa menguasai kosakata maka akan lebih baik penguasaan bahasa Inggrisnya. Dengan memiliki kosakata yang terbatas, para siswa akan menemukan kesulitan dalam menguasai keterampilan membaca dan lainnya. Dengan penguasaan kosakata yang baik berarti siswa memiliki kemampuan dalam memahami dan menggunakan kosa kata. Penguasaan kosakata itu sendiri berkaitan dengan kata-kata dan makna.

\section{Karakteristik Anak}

a. Anak-anak senang bermain

Salah satu ciri dari anak-anak adalah bahwa mereka suka bermain. Anak-anak senang belajar sambil bermain. Menurut definisi, permainan adalah kegiatan dengan aturan, tujuan dan unsur fun.

b. Asosiasi dan Memori

Anak-anak mudah memahami dan menghafal kosakata yang mereka lihat secara langsung. Untuk alasan ini, guru harus mengekspos siswa dengan situasi kehidupan nyata. Bantuan media visual, seperti gambar menjadi bagian integral dari peralatan profesional setiap guru.

\section{Media Ajar Flash Card}

Dalam proses pembelajaran, hadirnya media sangat diperlukan. Anita (2010:5) mendefinisikan media 
pembelajaran adalah setiap orang, bahan, alat, atau peristiwa yang dapat menciptakan kondisi yang memungkinkan pelajar untuk menerima pengetahuan, keterampilan, dan sikap. Media adalah sarana untuk menuju ke suatu tujuan. Salah satu media yang mampu menciptakan proses pembelajaran yang efektif adalah media flash card. Menurut Yusuf (2011:41) flash card adalah media pembelajaran dalam bentuk kartu bergambar yang berukuran $25 \times 30 \mathrm{~cm}$. Gambar-gambar dibuat menggunakan tangan atau foto, atau memanfaatkan gambar/foto yang sudah ada yang ditempelkan pada lembaran-lembaran flash card. Gambar-gambar yang ada pada flash card merupakan rangkaian pesan yang disajikan dengan keterangan setiap gambar yang dicantumkan pada bagian belakangnya. Pendapat lain dikemukakan Surana bahwa flash card merupakan salah satu bentuk permainan edukatif berupa pias-pias kartu yang memuat gambar dan kata yang sengaja dirancang untuk meningkatkan berbagai aspek, diantaranya: mengembangkan daya ingat, melatih kemandirian dan meningkatkan kosa kata. Berdasarkan beberapa pengertian flash card diatas dapat didefinisikan flash card adalah media visual (2 dimensi) berupa kartu yang memuat gambar yang berhubungan dengan pokok bahasan, sehingga dapat menyalurkan pesan dari sumber pesan kepada penerima pesan.

Menurut tim info dalam (balitacerdas.com:2007) media flash card merupakan metode pembelajaran yang menggunakan kartu permainan yang sangat efektif untuk membangun anak belajar membaca dan mengenal lingkungan sejak usia dini. Flash card sebenarnya sudah sangat populer di negara-negara maju, tetapi masih sangat sedikit sekali dikenal di Indonesia. Flash card ini bisa diterapkan untuk anak usia 4 bulan ke atas. Menurut tim info dalam (balita cerdas.com:2007), bahwa manfaat media flash card antara lain:

a. Belajar membaca sejak usia sedini mungkin (Glenn Doman).

b. Mengembangkan daya ingat otak kanan (Shichida).

c. Melatih kemampuan konsentrasi.

d. Meningkatkan perbendaharaan kata dengan cepat.

Seiring dengan perkembangan ilmu pengetahuan, flash card saat ini sudah mulai dikenal di mana-mana. Ada seorang ibu berprofesi sebagai wanita karir dalam info balita cerdas.com mengatakan bahwa dia merasakan keajaiban flash card yang dapat mendongkrak kemampuan putranya. Berawal dari kesadaran ibu tersebut yang tidak bisa 24 jam mengawasi putranya. Ibu tersebut menyiasati setiap harinya dengan meluangkan secara khusus tanpa diganggu aktivitas lain yaitu 30 menit sebelum membawa putranya ke TPA dan 1 jam setelah pulang kerja. Waktu 1,5 jam tersebut dimanfaatkan untuk mengenalkan putranya yang baru berusia 4 bulan satu per satu berbagai gambar yang menarik. Berawal dengan menggunting gambar binatang dari majalah bekas beliau sempat berpikir apakah bahwa "Apakah ada artinya saya mengajarkan hal-hal kecil ini?" Tetapi ibu tersebut teringat permainan kartu bergambar sangat baik untuk "olah raga" otak. Beliau merasa bahwa putranya sangat senang sekali melihat gambar yang berubah dengan cepat dan terusmenerus, si anak melihatnya dengan sungguh-sungguh. Perkembangan tersebut semakin tampak hasilnya begitu Andi (nama bayi tersebut) mulai bisa bicara. Sang ibu pun menjadi 
yakin dan bangga pada dirinya sendiri meskipun menjadi wanita karir tetapi tetap berhasil dalam mendidik anak. Dari situ kita bisa melihat bahwa jika waktu yang sebentar itu hanya untuk bermain yang tidak jelas, maka waktu tersebut akan hilang begitu saja. Dengan hal-hal seperti di atas, akan besar sekali manfaat yang diperoleh oleh anak kita.

\section{Bagaimana mengajarkan flash card pada anak?}

Pada prinsipnya mengenalkan flash card dilakukan secara sederhana dan yang terpenting dalam suasana yang menyenangkan, baik bagi ibu, ayah atau baby sitter yang mengajarkan dan bagi anak yang akan belajar. Menurut Sakane dalam (balitacerdas.com: 2007) beberapa tahap mengenalkan flash card pada anak antara lain:

a. Buat jadwal khusus dengan anak setiap hari untuk bermain flash card secara bersamasama. Dimulai dengan mengenalkan gambar binatang, gambar benda-benda menarik bertahap sampai anak mengenal semua benda yang ada di sekitarnya. Awalnya tidak perlu banyak-banyak tetapi terus-menerus kita tunjukkan maka suatu saat jika anak melihat benda yang sama tanpa melihat kartu dia akan memberikan reaksi baik menyebut nama benda yang pernah dia lihat atau reaksi lainnya. Setelah mengenalkan berbagai benda, kita bisa menambah dengan mengenalkan huruf, angka, profesi atau benda-benda lainnya agar pengetahuan anak bertambah sedikit-demi sedikit yang penting anak belajar dalam suasana hati yang gembira dan tidak dipaksakan apalagi dalam kondisi tertekan.

b. Untuk para orang tua yang bekerja dan waktu untuk bercengkerama dengan anak sangat terbatas, anda perlu memonitor segala sesuatunya sebelum berangkat ke kantor.

c. Memberikan pengarahan yang benar kepada baby sitter atau siapa saja yang mengasuh anak anda tentang kegiatan yang perlu dilakukan oleh anak anda selama anda tidak di rumah.

d. Buatlah daftar kegiatan anak anda dengan jelas, sehingga baby sitter anda tahu apa yang harus dilakukan setiap harinya. Hal ini penting karena dalam pengasuhan anak juga harus mampu memberikan stimulasi pada perkembangan kecerdasan anak, baik kecerdasan intelektual, emosi maupun perkembangan fisik dan sosialnya.

e. Usahakan jangan sampai babysitter anda hanya bertugas menjaga saja, tanpa memberikan stimulasi-stimulasi yang sangat diperlukan oleh anak anda. Akan sangat kasihan sekali anak anda nantinya, jika lingkungannya di masa yang sangat haus akan stimulasi ini ternyata tidak diberikan haknya yang akan menjadi harta yang paling berharga di masa depan. 


\section{Flash card yang dapat dikenalkan} pada anak

a. Flash card benda rumah

Flash card benda rumah merupakan sarana belajar bagi anak-anak untuk mengenal bendabenda yang ada di sekitar rumah. Tulisan nama benda dalam kartu sekaligus sebagai perangkat untuk belajar membaca. Pola gambar dan warna dapat menstimulus otak kanan. Ragam jenis aktivitas anak akan menjadi stimulus untuk berbagai jenis potensi kecerdasan yang dimiliki anak.

b. Flash card profesi

Berikut ini adalah flash card profesi yang dapat dipergunakan untuk belajar mengenai bermacammacam profesi atau pekerjaan yang dapat dilakukan ketika dewasa kelak. Selain itu juga dengan flash card profesi juga mengenalkan anak tentang ilmu IPS dan ilmu IPA dan ilmu lainnya.

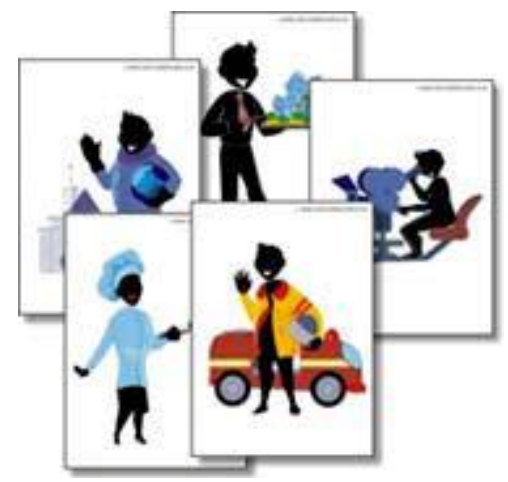

c. Animal and fruit flash card
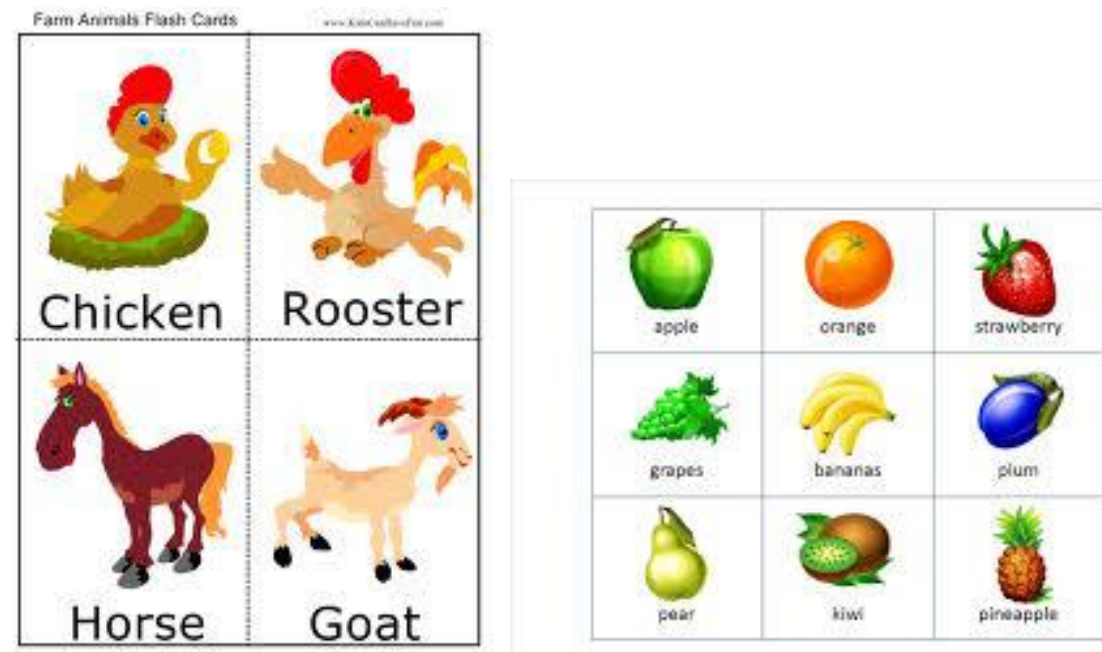

d. Flash card abjad 


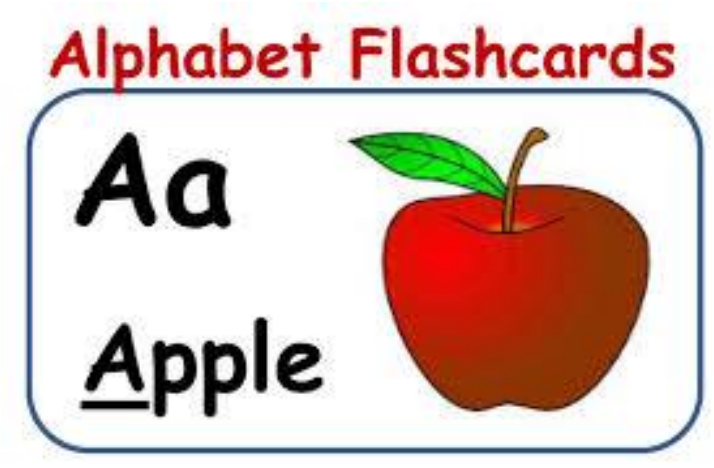

Beragam flash card yang dapat di print untuk bahan pembelajaran anak mengenal benda, warna, huruf, kata, dan sebagai sarana berbagai jenis kegiatan belajar anak lainnya.

\section{Kesimpulan}

Dalam perkembangannya, manusia pastilah melewati tahapantahapan berkembang dan berubah. Dalam proses kehidupan tersebut, seorang manusia belajar menyesuaikan diri dengan berbagai hambatan. Pada saat itulah dimulai pengaktifan karakter otak, baik yang bersifat kognitif yang ada di belahan otak kiri maupun afektif yang ada di belahan otak kanan. Pemberian stimulus yang tepat pada otak anak sedini mungkin, sangat mempengaruhi keberhasilan perkembangan selanjutnya. Hal penting karena otak pusat kendali dari semua aktivitas tubuh baik perilaku fisik maupun emosional. Perkembangan otak sebagai pusat koordinasi aktivitas manusia perlu mendapatkan stimulus yang sebanyak mungkin. Begitu pula kecerdasan anak tidak hanya dibentuk dari kecerdasan intelektual saja, tetapi juga kecerdasan emosional yang terdapat dalam otak kanan justru lebih

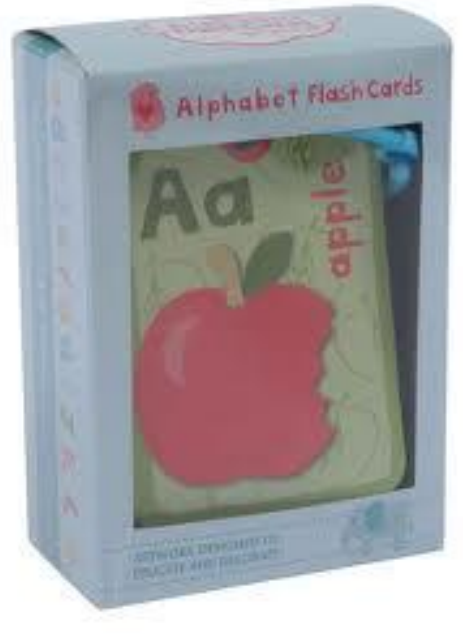

banyak menentukan keberhasilan hidup seseorang.

Menyeimbangkan otak kiri dan otak kanan dengan media flash card sangat efektif untuk mendongkrak kemampuan anak. Hal ini menjadi perhatian penting terutama bagi orang tua yang dua-duanya sama-sama bekerja. Dengan meluangkan waktu 1,5 jam saja secara rutin setiap hari akan bermanfaat yang luar biasa bagi pendidikan anak. Sehingga tidak ada alasan lagi bagi seorang ibu sebagai wanita karir untuk tidak punya waktu mendidik putra-putrinya.

\section{Daftar Pustaka}

Anggayana, I. W. A., Budasi, I. G., Lin, D. A., \& Suarnajaya, I. W. (2014). Affixation of bugbug dialect: A Descriptive Study. Jurnal Pendidikan Bahasa Inggris undiksha, 1(1).

AM Rukky Santoso. (2005). Mengembangkan

Kemampuan Otak Kanan Anak-anak. Jakarta: PT. Gramedia Pustaka utama.

Pam Galbraith dan Rachel C. Hoyer. (2005). 7 Kecerdasan Emosional Yang Dibutuhkan 
Anak Anda. Batam: Gospel Press

Siti Partini, dkk. (2006).

Perkembangan Peserta

Didik. Yogyakarta:

Universitas Negeri

Yogyakarta.

Tim Info. (2007). Flash card Balita

Cerdas. [on line] available

at:

http://info.balitacerdas.com/2 007/10/flash-card.html.

Abdul Syukur dkk,(2005), Eksklopedi Umum untuk Pelajar, Jakarta, PT Ichtiar Baru Van Houve.

Daryanto. ( 2010 ). Media Pembelajaran, Yogyakarta, Gava Media

Mohammad Asrori. (2007).

Psikologi Pembelajaran,

Bandung, CV. Wacana

Prima

Surana,

2012.

(http://www.balitacerdas.com

Sri Anitah.( 2010). Media Pembelajaran, Yuma

Pustaka, Surakarta

Tim Info. (2007). Flash card Balita

Cerdas. [on line] available at:

http://info.balitacerdas.com/2

007/10/flash-card.html. 